\title{
Stability of porridge pre-mixture made with Brazil nut flour and green banana flour with and without milk powder \\ Clarissa Reschke da CUNHA ${ }^{1 \star}$, Stephanie Lima dos SANTOS ${ }^{2}$, Vlayrton Tomé MACIEL ${ }^{1}$, Maria Luzenira de SOUZA ${ }^{3}$, Cydia de Menezes FURTADO ${ }^{3}$, Ana Vania CARVALHO ${ }^{4}$
}

\begin{abstract}
The mixture of Brazil nut flour and green banana flour can improve the nutritional value of school meals, allowing for the use of regional ingredients derived from family agriculture. This study aimed to assess the stability of porridge pre-mixtures made with Brazil nut flour and green banana flour during six months of storage. Two types of pre-mixture were evaluated: with and without milk powder. These mixtures were packed in polyethylene/metallized polyester film, vacuum-sealed, and stored at room temperature. The products were evaluated for physicochemical composition, and every 30 days for moisture content, water activity, titratable acidity, $\mathrm{pH}$, peroxide value and acidity of the lipid phase, total and thermotolerant coliforms, yeasts and molds, and sensory acceptance. There was no difference between the mixtures for the parameters evaluated. Moisture content, water activity, acidity of the lipid phase, and the yeast and mold count increased with storage time. The growth of yeasts and molds was more pronounced after 90 days of storage, when water activity reached the limit of 0.60 . Although both products had good sensory acceptance throughout the period of study, it is recommended that the shelf life does not exceed 90 days.
\end{abstract}

Keywords: Bertholletia excels; Musa sp.; porridge; shelf-life; sensory acceptance.

\section{Introduction}

The Brazil nut tree (Bertholletia excelsa Bonpl.) is native to the Amazon region. Its almond is rich in selenium, an antioxidant that has been associated with the prevention of cancer and formation of free radicals (Souza \& Menezes, 2004). It also contains all essential amino acids, with a high content of the sulphur amino acids (methionine and cysteine), which are usually insufficient in vegetable proteins (Souza $\&$ Menezes, 2008; Santos et al., 2010). The Brazil nut partially defatted flour, a byproduct of oil extraction, has about $25 \%$ fat, $40 \%$ protein, and $7 \mathrm{mg} \mathrm{kg}^{-1}$ selenium (Souza \& Menezes, 2004). Brazil nut flour has the advantage of having lower lipid content than that of raw nuts, and it can be used as an ingredient in many food products improving their nutritional value.

Banana (Musa sp) is a tropical fruit of great importance in Brazil, constituting an important part of the income of small producers. Green banana is rich in resistant starch (up to $84 \%$ ), a compound that has positive effects on the colon physiology and potentially prevents chronic non-communicable diseases such as diabetes (Teixeira et al., 1998; Freitas \& Tavares, 2005). Accordingly, green banana can be considered a functional food. An alternative to the consumption of fresh green banana is the use of banana flour, which is traditionally made with banana "comprida" (Musa paradisiaca), a variety rich in starch and widespread in the Amazon region. This flour, if properly prepared, preserves the functional properties of green banana and can be used in various products such as breads, cakes, cookies, pasta, and cereal bars (Pacheco-Delahaye \& Testa, 2005;
Fasolin et al., 2007; Borges et al., 2009, 2010; Vernaza et al., 2011).

The combination of Brazil nut flour and green banana flour results in a product with excellent nutritional value, which can be used in the formulation of cakes, breads, and cookies; in addition, it can also be used to prepare porridge for school meals (Souza et al., 2009). In the latter case, it allows for the use of regional ingredients with the purpose of improving the nutritional value of school meals, being in consonance with the Brazilian Law No. 1,947/2009, which states that 30\% of the total funds distributed for free school meals should be used in the purchase of food coming from family producers (Brasil, 2009).

Including porridge pre-mixture in school meals is an interesting idea, but the stability of the product is an issue of concern since high temperatures and relative humidity observed in the Amazon region contribute to decrease the shelf life of powder products. Another issue relates to the fact that a nutritive porridge should be prepared with milk. However, the access to some places in the Northern region is often difficult, making it hard to supply food products that take a lot of space, such as fluid milk. One way around this problem is to provide the product pre-mixed with milk powder. Therefore, this study aimed to assess the stability of porridge pre-mixtures made with Brazil nut flour and green banana flour with or without milk powder during six months of storage.

\section{Received 07 May, 2014}

Accepted 21 Aug., 2014 (006368)

${ }^{1}$ Embrapa Acre, Rio Branco, AC, Brasil, e-mail: clarissa.cunha@embrapa.br

${ }^{2}$ Faculdade do Acre, União Educacional do Norte - Uninorte, Rio Branco, AC, Brasil

${ }^{3}$ Unidade de Tecnologia de Alimentos - UTAL, Centro de Ciências Biológicas e da Natureza, Universidade Federal do Acre - UFAC, Rio Branco, AC, Brasil

${ }^{4}$ Embrapa Amazônia Oriental, Belém, PA, Brasil

${ }^{*}$ Corresponding author 


\section{Materials and methods}

\subsection{Porridge pre-mixture formulation}

The Brazil nut flour (2.51\% moisture, 5.24\% ash, $24.44 \%$ total protein, $51.03 \%$ lipid, $9.90 \%$ fiber, and $6.89 \%$ carbohydrate) and green banana flour (9.52\% moisture, $2.35 \%$ ash, $3.62 \%$ total protein, $0.53 \%$ lipid, $0.36 \%$ fiber, and $83.61 \%$ carbohydrate) were obtained from Olam Óleos da Amazônia (JLA Felício Import and Export, Rio Branco, AC, Brazil). The other ingredients were crystal sugar (Usinas Itamarati S.A., Nova Olimpia, MT, Brazil), instant whole milk powder $\left(\right.$ Ninho $^{\circledR}{ }^{\circledR}$, Nestlé ${ }^{\circledR}$ Brasil Ltd., São Paulo, SP, Brazil), and iodized salt (Cisne ${ }^{\circledR}$, Refinaria Nacional de Sal S.A., Cabo Frio, RJ, Brazil); all with expiration dates greater than the deadline for the completion of the experiment.

Two types of porridge pre-mixtures were prepared: A) with milk powder, for subsequent preparation of porridge with the addition of water ; B) without milk powder, for subsequent preparation of porridge with the addition of liquid milk. Preliminary studies were conducted in order to define the formulations of the pre-mixtures. Pre-mixture A was formulated with $300 \mathrm{~g}$ Brazil nut flour, $300 \mathrm{~g}$ green banana flour, $150 \mathrm{~g}$ sugar, $5 \mathrm{~g}$ salt, and $130 \mathrm{~g}$ milk powder (this amount is sufficient to prepare 1 liter of milk, according to manufacturer's instructions). Pre-mixture B contained the same ingredients, except for the milk powder. The mixtures were packed in stand-up pouches made from polyethylene/ metallized polyester film. The packages were vacuum-sealed using a sealing machine $\left(\right.$ Selovac $^{\circledR} 200 B$, Selovac ${ }^{\circledR}$ Ind. Com. Ltd., São Paulo, SP, Brazil). The products were stored at room temperature at the laboratory of Food Technology of Embrapa Acre, between October and March, period coinciding with the rainy season in the region. Temperature and relative humidity were recorded daily by the weather station of Embrapa Acre. The products were initially evaluated for physicochemical composition, and every 30 days for moisture content, water activity, titratable acidity, $\mathrm{pH}$, peroxide value and acidity of the lipid phase, total and thermotolerant coliforms, yeasts and molds, and sensory acceptance.

\subsection{Physicochemical analysis}

The pre-mixtures were evaluated in triplicate for $\mathrm{pH}$, using a digital pHmeter (ITPH 2100, Instrutemp Instrumentos de Medição Ltd., São Paulo, SP, Brazil); titratable acidity (Association of Official Analytical Chemists, 2012); soluble solids content ( ${ }^{\circ}$ Brix), using a digital refratometer (PAL-1, Atago Brasil Ltd., Ribeirão Preto, SP, Brazil); and water activity (aw), using an aw analyzer (AQUALAB CX-2, DECAGON Devices Inc., Pullman, WA, EUA), while moisture, ash, total lipid (Soxhlet method), total nitrogen (micro-Kjeldahl method), and crude fiber (van Soest method) contents were measured according to standard procedures (Association of Official Analytical Chemists, 2012). Total protein was calculated using the conversion factor 5.75 (for pre-mixture B) or 6.25 (for pre-mixture A). Carbohydrates were determined by difference. The lipid phase was extracted using the Soxhlet method (Association of Official Analytical Chemists, 2012) and evaluated for acidity and peroxide value (American Oil Chemists' Society, 2004). The extraction of the lipid phase is required because the methods for oil acidity and peroxide value are described for oil samples and cannot be used directly in complex food samples.

\subsection{Microbiological analysis}

The pre-mixtures were evaluated for total and thermotolerant $\left(45^{\circ} \mathrm{C}\right)$ coliforms $\left(\mathrm{MPN} \mathrm{g}^{-1}\right)$ and for yeasts and molds $\left(\mathrm{CFU} \mathrm{g}{ }^{-1}\right)$, according to Vanderzant \& Splittstoesser (1992). The detection limits were $3 \mathrm{MPN} \mathrm{g}^{-1}$ for coliforms and $1 \mathrm{CFU} \mathrm{g}{ }^{-1}$ for yeasts and molds.

\subsection{Experimental design}

A split-plot design was adopted. The factor studied was the addition of milk powder (treatments A, with milk powder and B, without milk powder). These trials were carried out in duplicate. The sub-plot was the storage time $(0,30,60,90,120,150$, and 180 days). The results were analyzed using analysis of variance (ANOVA) and Tukey's test to verify differences between the means $(p<0.05)$. The results of the microbiological tests were transformed into $\log (\mathrm{x})$ for statistical analysis. For the samples with results lower than the detection limit of the method, the statistical analysis was performed considering a value equal to the absolute limit of detection.

\subsection{Sensory acceptance}

The porridges made from pre-mixtures A and B were tested for sensory acceptance. The porridges were made as follows: the mixtures were added to 1 liter of water (A) or 1 liter of fluid milk (B) and heated over low heat under constant stirring. The cooking end point was defined as the moment when the viscosity increased enough for the porridge begins to come loose from the bottom of the pan.

The sensory acceptance tests were performed at the Laboratory for Sensory Analysis of Embrapa Acre using a randomized complete block experimental design with the monadic presentation technique (Meilgaard et al., 2006). Forty one untrained consumers with ages between 18 and 50 years evaluated the porridges. Each panelist evaluated two samples. The study was approved by the Research Ethics Committee (resolution \# 196/96, October 10th, 1996, Brazilian National Health Council - protocol number 02966312.5.0000.5010). Sensory evaluations were carried out only after the conclusion of the physicochemical and microbiological determinations. Only samples in accordance with the Brazilian legislation regarding the count of coliforms (Brasil, 2001), moisture content (Brasil, 2005a) and peroxide value and acidity of the lipid phase (Brasil, 2005b) were evaluated. The count of yeasts and molds was not considered impeditive to perform the sensory analysis since it did not have the maximum limit established by law (Brasil, 2001). The panelists were asked to read and sign an Informed Consent Form before performing the analyses. The samples were assessed by the panelists in individual booths under white light. Approximately $20 \mathrm{~g}$ of each sample were served at room 
temperature in plastic cups, coded with 3-digit numbers, and a teaspoon. The sensory attributes appearance, color, texture, aroma, flavor, and overall impression were measured using a 9-point-structured hedonic scale ( 1 = dislike extremely, 9 = like extremely). Results were analyzed using ANOVA, and the differences between the scores were evaluated using the Tukey's test $(\mathrm{p}<0.05)$.

\section{Results}

Pre-mixture A had higher protein and lipid contents and lower crude fiber and carbohydrate values $(\mathrm{p}<0.05)$ than those of pre-mixture B (Table 1). According to data provided by the manufacturer, the whole milk powder used in this study had higher protein values (26\%) and lipids (27\%) and lower values of fiber $(0 \%)$ and carbohydrates $(38 \%)$ than those of the pre-mixture without milk powder (B). Thus, the addition of milk powder contributed to increase the percentages of protein and lipid in the pre-mixture A. Since moisture remained almost the same in both samples, the levels of fiber and carbohydrates were proportionally lower. In practice, the difference in composition between the two pre-mixtures is of little importance since the porridge that will be made from pre-mixture B will have the addition of milk, resulting in a final composition that is probably similar to that of the porridge made from pre-mixture A.

Table 1. Average chemical composition $(n=2)$ of the porridge premixtures made with milk powder (A) and without milk powder (B).

\begin{tabular}{lcc}
\hline \multicolumn{1}{c}{ Component (\%) } & Pre-mixture A & Pre-mixture B \\
\hline Moisture & $3.53 \pm 0.45^{\mathrm{a}}$ & $4.54 \pm 0.98^{\mathrm{a}}$ \\
Ash & $6.42 \pm 0.89^{\mathrm{a}}$ & $4.72 \pm 0.48^{\mathrm{a}}$ \\
Total protein & $12.24 \pm 0.94^{\mathrm{a}}$ & $9.11 \pm 0.41^{\mathrm{b}}$ \\
Lipid & $21.14 \pm 0.99^{\mathrm{a}}$ & $16.06 \pm 0.27^{\mathrm{b}}$ \\
Crude fiber & $5.28 \pm 0.34^{\mathrm{b}}$ & $7.15 \pm 0.68^{\mathrm{a}}$ \\
Carbohydrate & $51.41 \pm 0.99^{\mathrm{b}}$ & $58.43 \pm 0.92^{\mathrm{a}}$ \\
\hline
\end{tabular}

a,b Means with the same letter in the same row are not statistically different $(p>0.05)$.

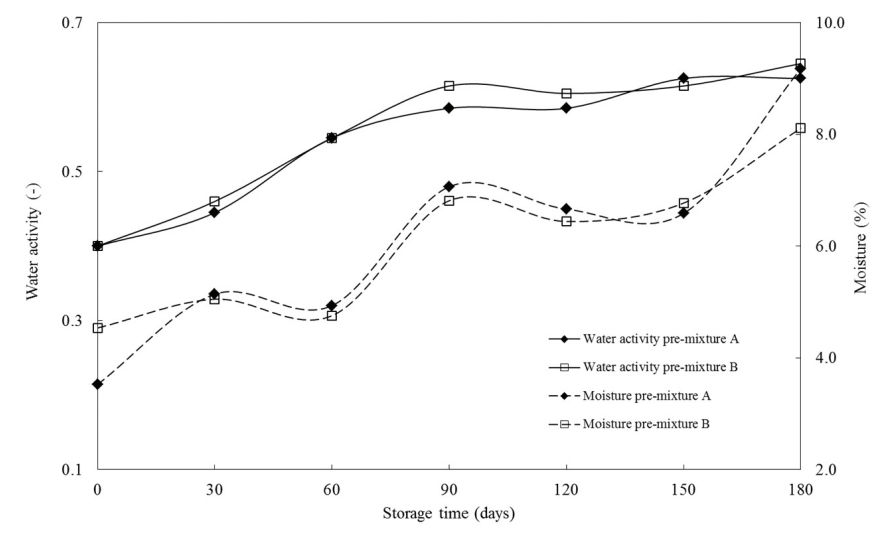

Figure 1. Changes in moisture and water activity of pre-mixtures A (with milk powder) and B (without milk powder) during 180 days of storage at room temperature.
Water activity and moisture significantly increased with time $(\mathrm{p}<0.05)$ for both pre-mixtures A and B (Figure 1). There was no significant difference between the treatments $(\mathrm{p}>0.05)$ or time $\mathrm{x}$ treatment interaction $(\mathrm{p}>0.05)$ for these parameters.

Changes in $\mathrm{pH}$ and titratable acidity of pre-mixtures $\mathrm{A}$ and B during storage are shown in Figure 2. For titratable acidity, there was no significant difference $(\mathrm{p}>0.05)$ between the treatments or the times evaluated and no time $\mathrm{x}$ treatment interaction $(\mathrm{p}>0.05)$. With respect to $\mathrm{pH}$, there were significant changes with storage time $(\mathrm{p}<0.05)$, on day $180, \mathrm{pH}$ was lower than that observed in the earlier days of storage.

For peroxide values (Figure 3 ), there was no significant difference $(p>0.05)$ between treatments or the times evaluated and no time $x$ treatment interaction $(p>0.05)$. The acidity of the lipid phase, on the other hand, significantly increased with storage time $(\mathrm{p}<0.05)$ (Figure 3$)$.

With respect to microbiological stability, all samples showed negative counts $\left(<3 \mathrm{MPN} \mathrm{g}^{-1}\right)$ for total and thermotolerant $\left(45^{\circ} \mathrm{C}\right)$ coliforms. Therefore, the samples were in compliance with Brazilian law, which states that the thermotolerant $\left(45^{\circ} \mathrm{C}\right)$ coliforms count must be lower than $10^{2} \mathrm{MPN} \mathrm{g}^{-1}$ for products to be consumed after the addition of liquid and heating (Brasil, 2001). This result proves that both the flour manufacturing process and the processing of porridge pre-mixtures were performed in accordance with the requirements for good manufacturing practices.

On the other hand, the mold and yeast count significantly increased ( $\mathrm{p}<0.05$ ) with storage time (Figure 4$)$, but there was no significant difference between pre-mixtures $A$ and $B$.

With respect to sensory analysis, there was no significant difference $(p>0.05)$ between the two pre-mixtures for the parameters evaluated (appearance, aroma, texture, flavor, and overall impression) at any time during storage (Table 2). The only exception occurred right after preparation (zero days of storage), when the porridge made with pre-mixture A had a slightly higher average score for aroma than porridge made from pre-mixture $B$.

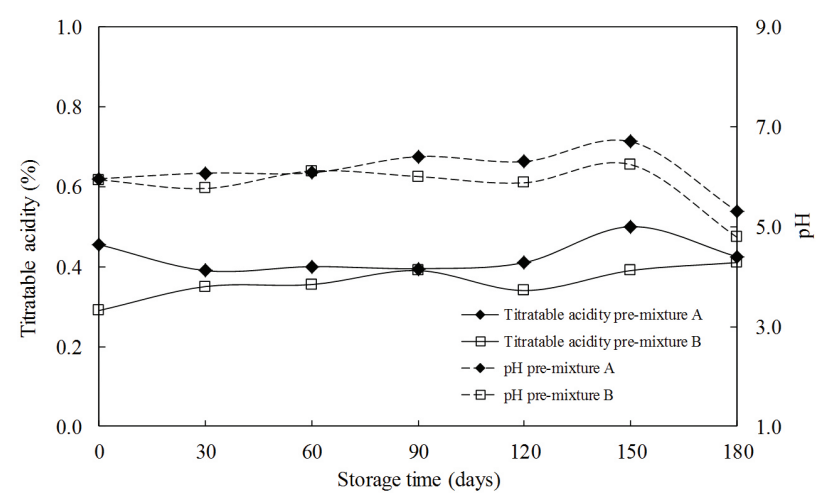

Figure 2. Changes in $\mathrm{pH}$ and titratable acidity of pre-mixtures A (with milk powder) and B (without milk powder) during 180 days of storage at room temperature. 


\section{Discussion}

The protein contents of pre-mixtures A and B were $12.24 \%$ and $9.11 \%$, respectively (Table 1 ). Since the porridges usually consumed by children in the Amazon region are made with water and banana flour only, which contains low protein content (only 3.6\%), it can be said that the inclusion of Brazil nut flour in the formulation resulted in a significant increase in protein levels, improving the nutritional value of the meal.

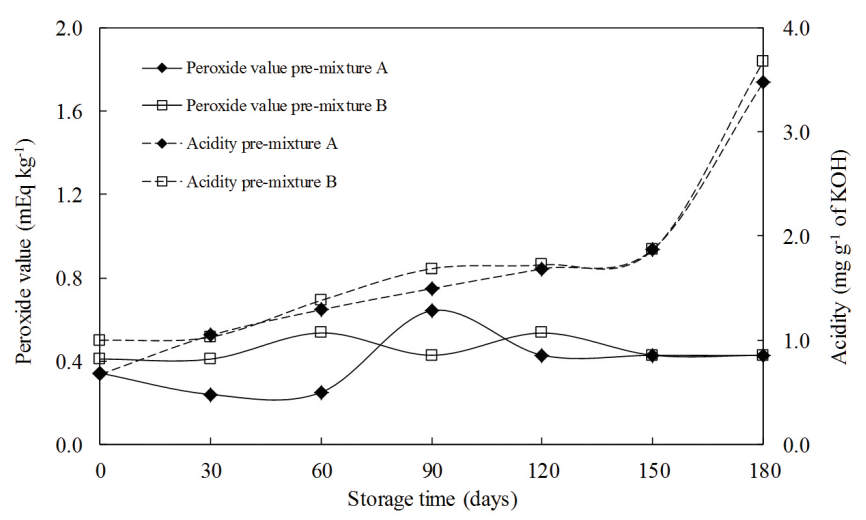

Figure 3. Changes in peroxide value and acidity of the lipid phase of pre-mixtures A (with milk powder) and B (without milk powder) during 180 days of storage at room temperature.

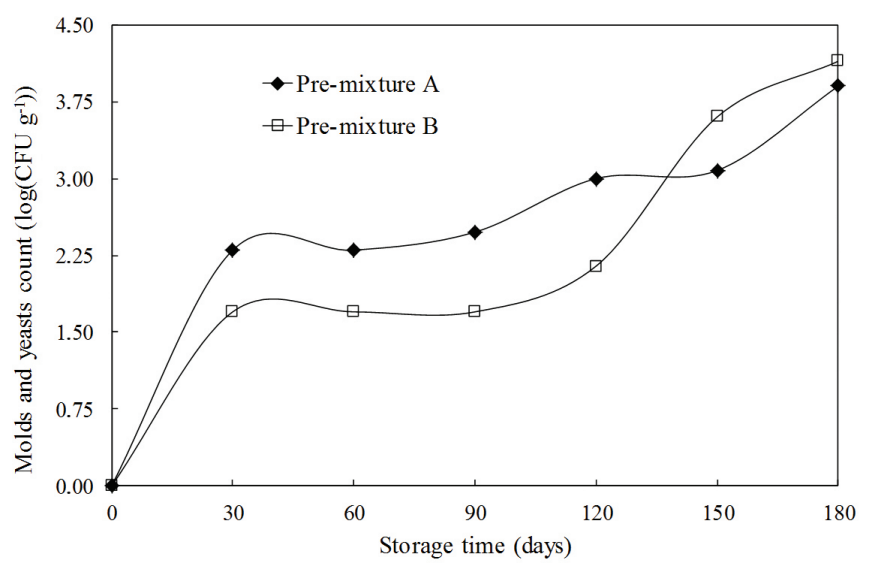

Figure 4. Mean values of the count of molds and yeasts of pre-mixtures A (with milk powder) and B (without milk powder) during 180 days of storage at room temperature.
A balanced diet for children should provide $9-15 \%$ of energy from protein, $35-45 \%$ from lipids and $45-55 \%$ from carbohydrates (Cerezal-Mezquita et al., 2007). As for the pre-mixture $A$, the percentages of the total energy due to proteins, lipids, and carbohydrates were $11.0,42.8$, and $46.2 \%$, respectively. As for the pre-mixture $\mathrm{B}$, these values were near ideal $(8.8,34.8$ and $56.4 \%)$ even before addition of milk. Thus, the developed formulations may be considered adequate for feeding school age children.

The increase in moisture and water activity with time (Figure 1) indicated the transfer of water vapor through the packaging, which may have occurred due to permeation through packing material or sealing faults. Alves et al. (2008) observed that, for milk powder stored in metallized polyester I polyethylene packs, water activity also increased with time, particularly when storage was carried out at high temperature $\left(35^{\circ} \mathrm{C}\right)$ and high relative humidity $(90 \%)$. High temperatures increase the water vapor permeability of the packaging material. In the present study, the temperature and relative humidity during the six months of storage were quite high, with mean values of $26.39 \pm 1.33^{\circ} \mathrm{C}$ and $87.91 \pm 6.13 \%$, respectively.

Despite the significant increase with time, the average moisture content of the pre-mixtures (8.65\%) at 180 days of storage was smaller than the maximum established by Brazilian legislation for flour, which is 15\% (Brasil, 2005a). As expected, the increase in moisture was accompanied by an increase in water activity. In general, water activities below 0.70 inhibit the growth of most microorganisms, and values below 0.60 inhibit even xerophilic molds and osmophilic yeasts, which can still grow in the range from 0.60 to 0.65 (Troller, 1980). In this study, the water activity values were below 0.70 throughout the storage period.

The decrease in $\mathrm{pH}$ at the end of the storage time (Figure 2) was not accompanied by an increase in titratable acidity, which remained constant during the entire storage period. This result can be explained by the higher moisture observed at the end of storage, which contributed to dilute organic acids and increase the concentration of ions $\mathrm{H}^{+}$. Borges et al. (2010) evaluated cake pre-mixtures made with green banana flour and also observed a decrease in $\mathrm{pH}$ after 120 days of storage.

The peroxide values of the samples remained low during the whole storage period (Figure 3), with an average value $\left(0.42 \mathrm{mEq} \mathrm{kg}^{-1}\right)$ below the maximum limit specified by Brazilian legislation for cold pressed unrefined oils, which is $15 \mathrm{mEq} \mathrm{kg}{ }^{-1}$ (Brasil, 2005b). Peroxide value is indicative of oxidative rancidity

Table 2. Average scores $(n=41)$ given to the sensory attributes of appearance, aroma, texture, flavor, and overall impression for the porridges prepared from pre-mixtures A (with milk powder) and B (without milk powder) at different storage times.

\begin{tabular}{|c|c|c|c|c|c|c|c|c|c|c|c|c|c|c|}
\hline \multirow{3}{*}{ Sensory attribute } & \multicolumn{14}{|c|}{ Storage time (days)/ Pre-mixture (A/B) } \\
\hline & \multicolumn{2}{|c|}{$\mathbf{0}$} & \multicolumn{2}{|c|}{30} & \multicolumn{2}{|c|}{60} & \multicolumn{2}{|c|}{90} & \multicolumn{2}{|c|}{120} & \multicolumn{2}{|c|}{150} & \multicolumn{2}{|c|}{180} \\
\hline & $\mathbf{A}$ & B & $\mathbf{A}$ & B & $\mathbf{A}$ & B & A & B & A & B & A & B & A & B \\
\hline Appearance & $7.0^{\mathrm{a}}$ & $6.8^{\mathrm{a}}$ & $6.4^{\mathrm{a}}$ & $6.2^{\mathrm{a}}$ & $7.1^{\mathrm{a}}$ & $7.1^{\mathrm{a}}$ & $6.8^{\mathrm{a}}$ & $6.7^{\mathrm{a}}$ & $6.4^{\mathrm{a}}$ & $6.6^{\mathrm{a}}$ & $6.5^{\mathrm{a}}$ & $6.7^{\mathrm{a}}$ & $6.8^{\mathrm{a}}$ & $6.8^{\mathrm{a}}$ \\
\hline Aroma & $7.5^{\mathrm{a}}$ & $7.1^{\mathrm{b}}$ & $7.0^{\mathrm{a}}$ & $6.7^{\mathrm{a}}$ & $7.4^{\mathrm{a}}$ & $7.3^{\mathrm{a}}$ & $6.9^{\mathrm{a}}$ & $7.1^{\mathrm{a}}$ & $6.9^{\mathrm{a}}$ & $7.1^{\mathrm{a}}$ & $7.2^{\mathrm{a}}$ & $7.1^{\mathrm{a}}$ & $6.9^{\mathrm{a}}$ & $7.0^{\mathrm{a}}$ \\
\hline Texture & $7.6^{\mathrm{a}}$ & $7.5^{\mathrm{a}}$ & $6.8^{\mathrm{a}}$ & $6.9^{\mathrm{a}}$ & $7.4^{\mathrm{a}}$ & $6.9^{\mathrm{a}}$ & $7.2^{\mathrm{a}}$ & $7.2^{\mathrm{a}}$ & $6.8^{\mathrm{a}}$ & $7.1^{\mathrm{a}}$ & $7.0^{\mathrm{a}}$ & $7.0^{\mathrm{a}}$ & $7.1^{\mathrm{a}}$ & $7.3^{\mathrm{a}}$ \\
\hline Flavor & $7.9^{\mathrm{a}}$ & $7.5^{\mathrm{a}}$ & $7.5^{\mathrm{a}}$ & $7.3^{\mathrm{a}}$ & $7.8^{\mathrm{a}}$ & $7.5^{\mathrm{a}}$ & $7.4^{\mathrm{a}}$ & $7.7^{\mathrm{a}}$ & $7.7^{\mathrm{a}}$ & $7.5^{\mathrm{a}}$ & $7.2^{\mathrm{a}}$ & $7.5^{\mathrm{a}}$ & $7.1^{\mathrm{a}}$ & $7.3^{\mathrm{a}}$ \\
\hline Overall impression & $7.6^{\mathrm{a}}$ & $7.5^{\mathrm{a}}$ & $7.2^{\mathrm{a}}$ & $6.8^{\mathrm{a}}$ & $7.5^{\mathrm{a}}$ & $7.5^{\mathrm{a}}$ & $7.3^{\mathrm{a}}$ & $7.3^{\mathrm{a}}$ & $7.4^{\mathrm{a}}$ & $7.4^{\mathrm{a}}$ & $7.0^{\mathrm{a}}$ & $7.2^{\mathrm{a}}$ & $7.2^{\mathrm{a}}$ & $7.4^{\mathrm{a}}$ \\
\hline
\end{tabular}

\footnotetext{
${ }^{a}$ Means with the same letter in the same row and at the same time are not statistically different $(\mathrm{p}>0.05)$.
} 
and is always associated with the presence of oxygen, which reacts with unsaturated fatty acids resulting in the formation of peroxides and hydroperoxides (Ramalho \& Jorge, 2006). Our results show that the packaging used offered good barrier against oxygen under the conditions of the study, and that the use of vacuum was effective in avoiding autoxidation of the residual oil present in the porridge pre-mixtures.

The acidity of the lipid phase increased with storage time (Figure 3), reaching, at day 180 , a value $\left(3.6 \mathrm{mg} \mathrm{g}^{-1}\right.$ of $\left.\mathrm{KOH}\right)$ close to the maximum limit established by Brazilian legislation for cold pressed unrefined oils, which is $4.0 \mathrm{mg} \mathrm{g}^{-1}$ of $\mathrm{KOH}$ (Brasil, 2005b). The acidity of the lipid phase measures the free fatty acids content and is an indicative of hydrolytic rancidity (Ramalho \& Jorge, 2006). The increase in hydrolytic rancidity with time was related to the increase in moisture (Figure 1) and to the high temperatures observed during this study since the reaction is accelerated by the presence of water and by heat (Ramalho \& Jorge, 2006).

Regarding the microbiological stability, the mold and yeast count increased with storage time for pre-mixtures A and B (Figure 4). Although Brazilian legislation does not establish a maximum limit for this parameter in products to be consumed after the addition of liquid and heating (Brasil, 2001), the increase in the count of yeasts and molds is undesirable because it can lead to quality defects (bad flavor, nutritional losses, etc.) and negatively influence food safety (due to the production of toxins, for example). At 120 days of storage, the count of yeasts and molds of pre-mixture $\mathrm{A}, 10^{3} \mathrm{CFU} \mathrm{g}^{-1}$, was equal to the maximum limit allowed by former Brazilian law (Brasil, 1978). The count of yeasts and molds continued to increase with storage time (Figure 4), but even after 180 days the mean value, $1.1 \times$ $10^{4} \mathrm{CFU} \mathrm{g}^{-1}$, was lower than that previously reported for other products containing nuts. Granada et al. (2003), evaluating commercial samples of granola, found mold and yeast count between $12 \times 10^{4} \mathrm{CFU} \mathrm{g}^{-1}$ and $33 \times 10^{6} \mathrm{CFU} \mathrm{g}^{-1}$.

The increase in the count of yeasts and molds was accompanied by an increase in moisture content. The greater availability of water probably favored the growth of these microorganisms. However, it must be noted that the water activity, although it increased with time, remained below 0.60 , which is considered as a threshold value for microbial growth (Troller, 1980) up to 90 days of storage. Thus, the increase in the count of yeasts and molds observed during this period of time was unexpected. A possible explanation for this result is that the entry of water vapor in the package must have occurred at a rate greater than the rate of diffusion inside the product. Thus, before the water diffused into the product (which occurs slowly), there were points inside the package where the moisture content was higher than that in the sample as a whole. In those points, there were probably favorable conditions (high water activity) for the fungi to grow. From 90 days of storage on, the increase in yeast and mold count was greater, coinciding with the time at which the water activity of the samples became higher than 0.60 .

Another point that should be discussed is the fact that the samples were vacuum-packed, which in principle should have prevented the growth of fungi since most molds and yeasts in foodstuffs are aerobic (Jay, 2000). However, the application of vacuum does not remove all oxygen from the packed product
(Hotchkiss, 1988; Vermeiren et al., 1999; Cruz et al., 2006). In addition, metallized polyester / polyethylene packages exhibit some permeability to oxygen (Alves et al., 2008). Although the oxygen permeability was not measured in this study, it can be stated that it was sufficient to allow the growth of molds and yeasts. It is also important to emphasize that, despite foodborne fungi have long been considered to be obligate aerobes, nowadays there is considerable evidence indicating that some of these fungi can grow under facultative anaerobic conditions (Marchant et al., 1994; Wainwright et al., 1994; Panagiotou et al., 2005; Taniwaki et al., 2009). Consequently, there is some concern that modified atmospheres with reduced oxygen may not effectively control or prevent fungal growth (Taniwaki et al., 2009), and this may explain our findings.

With respect to sensory analysis, the average scores were higher than 6 for all parameters tested (Table 2), indicating good sensory acceptance. Regarding flavor, the scores were even higher (above 7), showing that this parameter was the one that most positively influenced acceptance. On the other hand, appearance received the lowest scores, suggesting that this may be a characteristic to be improved in the product.

It was possible to observe a slight trend towards reduction in flavor scores with time (Table 2), showing that part of consumers were able to detect the loss of quality as evidenced by changes in moisture (Figure 1), acidity of the lipid phase (Figure 3), and yeast and mold count (Figure 4).

At zero days of storage, the porridge made with pre-mixture A had a higher average score for aroma than that of the porridge made with pre-mixture B (Table 2). However, this result was punctual and does not seem to have any correlation with any physicochemical determination carried out in the pre-mixtures. Possibly, the difference in aroma reflected the quality of fluid milk used in the preparation of porridge from pre-mixture B.

\section{Conclusions}

The porridges prepared from pre-mixtures made from Brazil nut flour and green banana flour, with and without milk powder, had good acceptability throughout the studied period. Despite that, both samples presented an increase in moisture content and in the counts of molds and yeasts, the latter especially after 90 days of storage, when water activity reached the limit of 0.60 . The results showed that the product, in both forms of presentation, has good potential to be distributed in areas of difficult access in the Northern region. However, it is recommended that the expiration date does not exceed 90 days. Alternatively, further research should be conducted to find a package with better moisture barrier that ensures a longer period of shelf life.

\section{Acknowledgements}

The authors thank SEBRAE (Serviço Brasileiro de Apoio à Micro e Pequenas Empresas), FINEP (Financiadora de Estudos e Projetos) and the Brazilian Ministry of Science and Technology for the financial support and also Olam Óleos da Amazônia for supplying the raw materials. 


\section{References}

Alves, R. M. V., Jaime, S. B. M., Ito, D., \& Moreira, C. Q. (2008). Influência das propriedades de barreira de embalagens flexíveis na estabilidade de leite em pó integral. Brazilian Journal of Food Technology, 11(1), 46-53.

Association of Official Analytical Chemists - AOAC. (2012). Official methods of analysis of the Association of Official Analytical Chemists (19th ed.). Washington: AOAC.

American Oil Chemists' Society - AOCS. (2004). Official methods and recommended practices of the American Oil Chemists' Society. Champaign: AOCS.

Borges, A. M., Pereira, J.; Silva Jr., A., Lucena, E. M. P., \& Sales, J. C. (2010). Estabilidade da pré-mistura de bolo elaborada com $60 \%$ de farinha de banana verde. Ciência e Agrotecnologia, 34(1), 173-181. http://dx.doi.org/10.1590/S1413-70542010000100022

Borges, A. M., Pereira, J., \& Lucena, E. M. P. (2009). Caracterização da farinha de banana verde. Ciência e Tecnologia de Alimentos, 29(2), 333-339. http://dx.doi.org/10.1590/S0101-20612009000200015

Brasil, Ministério da Saúde, Comissão Nacional de Normas e Padrões para Alimentos. (1978). Normas Técnicas Especiais, do Estado de São Paulo, revistas pela CNNPA, relativas a alimentos (e bebidas), para efeito em todo território brasileiro (Resolução CNNPA no 12 , de 24 de setembro de 1978). Diário Oficial da República Federativa do Brasil.

Brasil, Ministério da Saúde, Agência Nacional de Vigilância Sanitária. (2001). Regulamento Técnico sobre Padrões Microbiológicos para Alimentos (Resolução RDC n 12, de 2 de janeiro de 2001). Diário Oficial da República Federativa do Brasil.

Brasil, Ministério da Saúde, Agência Nacional de Vigilância Sanitária. (2005a). Regulamento técnico para produtos de cereais, amidos, farinhas e farelos (Resolução ANVISA n 263 , de 22 de setembro de 2005). Diário Oficial da República Federativa do Brasil.

Brasil, Ministério da Saúde, Agência Nacional de Vigilância Sanitária. (2005b). Regulamento técnico para óleos vegetais, gorduras vegetais e creme vegetal (Resolução RDC no 270, de 22 de setembro de 2005). Diário Oficial da República Federativa do Brasil.

Brasil. (2009). Atendimento da alimentação escolar e dá outras providências (Lei no 11.947 , de 16 de junho de 2009). Diário Oficial da República Federativa do Brasil.

Cerezal-Mezquita, P., Carrasco-Verdejo, A., Pinto-Tapia, K., RomeroPalacios, N., \& Arcos-Zavala, R. (2007). Suplemento alimenticio de alto contenido proteico para niños de 2-5 años: desarrollo de la formulación y aceptabilidad. Interciencia, 32(12), 857-864.

Cruz, R. S., Soares, N. F. F., \& Andrade, N. J. (2006). Evaluation of oxygen absorber on antimicrobial preservation of lasagna-type fresh pasta under vacuum packed. Ciência e Agrotecnologia, 30(6), 1135-1138. http://dx.doi.org/10.1590/S1413-70542006000600015

Fasolin, L. H., Almeida, G. C., Castanho, P. S., \& Netto-Oliveira, E. R. (2007). Biscoitos produzidos com farinha de banana: avaliações química, física e sensorial. Ciência e Tecnologia de Alimentos, 27(3), 524-529. http://dx.doi.org/10.1590/S0101-20612007000300016

Freitas, M. C. J., \& Tavares, D. Q. (2005). Caracterização do grânulo de amido de bananas (Musa AAA-NANICÃO E Musa AAB-TERRA). Ciência e Tecnologia de Alimentos, 25(2), 217-222. http://dx.doi. org/10.1590/S0101-20612005000200005

Granada, G., Rosa, V., Zambiasi, R., \& Koetz, P. (2003). Caracterização de granolas comerciais. Ciência e Tecnologia de Alimentos, 23(1), 87-91. http://dx.doi.org/10.1590/S0101-20612003000100018

Hotchkiss, J. (1988). Experimental approaches to determining the safety of food packaged in modified atmosphere. Food Technology, 42(9), 55-64.
Jay, J. M. (2000). Modern food microbiology (6th ed.). Gaithersburg: Aspen Publishers. 637 p. http://dx.doi.org/10.1007/978-1-46154427-2

Marchant, R., Nigan, P., \& Banat, I. M. (1994). An unusual facultatively anaerobic filamentous fungus isolated under prolonged enrichment culture conditions. Mycological Research, 98(7), 757-760. http:// dx.doi.org/10.1016/S0953-7562(09)81050-2

Meilgaard, M., Civille, G. V., \& Carr, B. T. (2006). Sensory evaluation techniques (4th ed.). Boca Raton: CRC Press. 448 p. http://dx.doi. org/10.1201/b16452

Pacheco-Delahaye, E., \& Testa, G. (2005). Evaluación nutricional, física y sensorial de panes de trigo y plátano verde. Interciencia, 30(5), 300-304.

Panagiotou, G., Granato Villas-Boas, S., Christakopoulos, P., Nielsen, J., \& Olsson, L. (2005). Intracellular metabolite profiling of Fusarium oxysporum converting glucose to ethanol. Journal of Biotechnology, 115(4), 425-434. PMid:15639104. http://dx.doi.org/10.1016/j. jbiotec.2004.09.011

Ramalho, V. C., \& Jorge, N. (2006). Antioxidantes utilizados em óleos, gorduras e alimentos gordurosos. Química Nova, 29(4), 755-760. http://dx.doi.org/10.1590/S0100-40422006000400023

Santos, O. V., Lopes, A. S., Azevedo, G. O., \& Santos, A. C. (2010). Processing of Brazil-nut flour: characterization, thermal and morphological analysis. Ciência e Tecnologia de Alimentos, 30(Supl. 1), 264-269. http://dx.doi.org/10.1590/S0101-20612010000500040

Souza, J. M. L., Leite, F. M. N., Medeiros, M. J. \& Brito, P. A. C. (2009). Farinha mista de banana verde e de castanha-do-brasil. Brasília: Embrapa Informação Tecnológica. 49 p.

Souza, M. L., \& Menezes, H. C. (2008). Otimização do processo de extrusão termoplástica da mistura castanha do Brasil com farinha de mandioca. Ciência e Tecnologia de Alimentos, 28(3), 659-667. http://dx.doi.org/10.1590/S0101-20612008000300023

Souza, M. L., \& Menezes, H. C. (2004). Processamentos de amêndoa e torta de castanha-do-brasil e farinha de mandioca: parâmetros de qualidade. Ciência e Tecnologia de Alimentos, 24(1), 120-128. http:// dx.doi.org/10.1590/S0101-20612004000100022

Taniwaki, M. H., Hocking, A. D., Pitt, J. I., \& Fleet, G. H. (2009). Growth and mycotoxin production by food spoilage fungi under high carbon dioxide and low oxygen atmospheres. International Journal of Food Microbiology, 132(2-3), 100-108. PMid:19428138. http://dx.doi.org/10.1016/j.ijfoodmicro.2009.04.005

Teixeira, M. A. V., Ciacco, C. F., Tavares, D. Q. \& Bonezzi, A. N. (1998). Ocorrência e caracterização do amido resistente em amidos de milho e banana. Ciência e Tecnologia de Alimentos, 18(2), 246-246. http://dx.doi.org/10.1590/S0101-20611998000200019

Troller, J. A. (1980). Influence of water activity on microorganisms in foods. Food Technology, 34(5),76-82.

Vanderzant, C., \& Splittstoesser, D. F. (1992). Compendium of methods for the microbiological examination of foods (3rd ed.). Washington: American Public Health Association. 1219 p. PMid:22059567.

Vermeiren, L., Devlieghere, F., Van Beest, M., Kruijf, N., \& Debevere, J. (1999). Development in the active packaging of foods. Trends in Food Science and Technology, 10(3), 77-86. http://dx.doi. org/10.1016/S0924-2244(99)00032-1

Vernaza, M. G., Gularte, M. A., \& Chang, Y. K. (2011). Addition of green banana flour to instant noodles: rheological and technological properties. Ciência e Agrotecnologia, 35(6), 1157-1165. http://dx.doi. org/10.1590/S1413-70542011000600016

Wainwright, M., Ali, T. A., \& Killham, K. (1994). Anaerobic growth of fungal mycelium from soil particles onto nutrient-free silica gel. Mycological Research, 98(7), 761-762. http://dx.doi.org/10.1016/ S0953-7562(09)81051-4 